\title{
SYDENHAM'S ORIGINAL TREATISE ON SMALLPOX WITH A PREFACE, AND DEDICATION TO THE EARL OF SHAFTESBURY, BY JOHN LOCKE
}

by

\section{KENNETH DEWHURST}

When Sydenham's Methodus Curandi Febres appeared in I666 his closest medical colleague was Dr. John Mapletoft (physician to the Ioth Earl of Northumberland) who introduced his old schoolfellow John Locke to him. This first book was dedicated to Robert Boyle, who had greatly encouraged his study of fevers; and, at a later date, Boyle also stimulated Locke's interest in medicine and science. But although Locke got a copy of Sydenham's book as soon as it came out and made copious notes from it, he still continued with his chemical experiments at Oxford, where he was well on the way to becoming a thoroughgoing iatro-chemist, until his appointment as physician to Lord Ashley (later the Ist Earl of Shaftesbury) brought him into close association with Sydenham. The latter's influence completely changed the direction of Locke's medical interests. Henceforth he forsook the laboratory for the bedside; and shortly after his arrival in the metropolis he began to accompany Sydenham on visits to patients in order to see for himself (as Boyle had previously done) the efficacy of his methods.

I perceive my friend Mr. Locke, [wrote Sydenham to Boyle in 1668 ] hath troubled you with an account of my practice as he hath done himself in visiting with me very many of my variolous patients especially.*

During the next five years Locke and Sydenham became more intimately associated; as Boyle's interests were more scientific than medical, and Mapletoft's duties frequently took him away from London. The earliest written evidence of their collaboration is Locke's Latin poem which prefixed the second edition (1668) of Sydenham's book on fevers. A few lines from Payne's $\dagger$ translation shows his admiration of Sydenham's methods:

Still Fever burns and all her skill defies,

Till Sydenham's wisdom plays a double part

Quells the disease and helps the failing Art.

Other evidence of their collaboration is to be found in a series of medical essays to which they both contributed. The earliest essay, Anatomie (1668) $\ddagger$,

* Boyle, Robert, Works (1 744), v, 567. † Payne, J. F., Thomas Sydenham (1900), p. 129.

$\ddagger$ P.R.O. File $30 / 24 / 47 / 2$, reproduced in 'Locke and Sydenham on the Teaching of Anatomy', by K. Dewhurst, Medical History (1958), I1, I-12. 
44 Sagaciffimi vin, ot prach ic faliuffi 3 tongri Trome Syonlam amici sui phinimem Cotenir hractaky be

$$
V_{2} \text { riolis. an. } 1669 .
$$

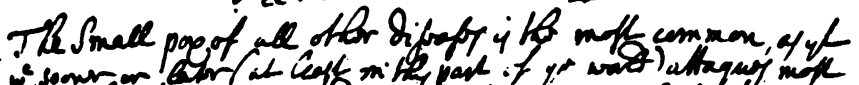

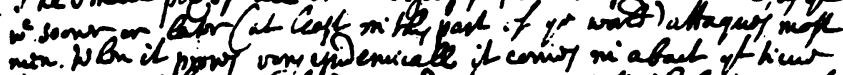

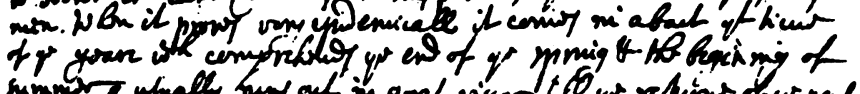

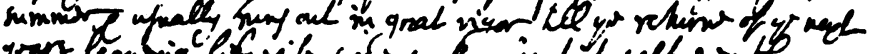

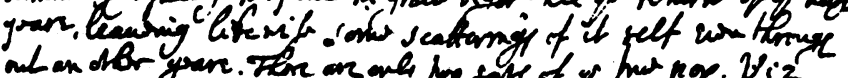

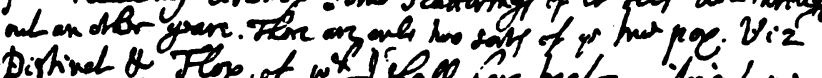

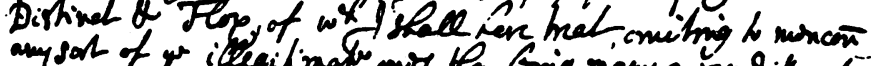

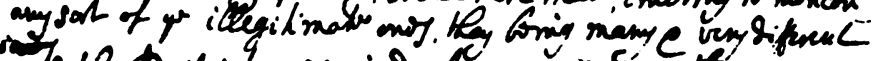

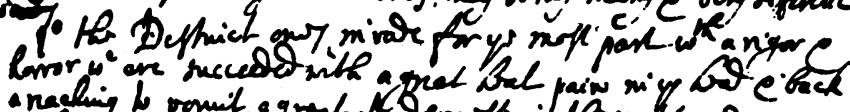

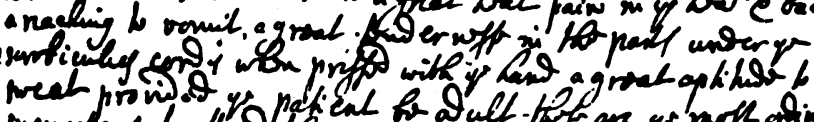

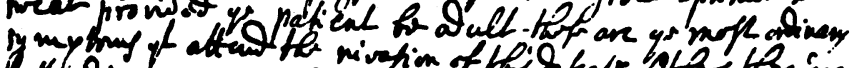

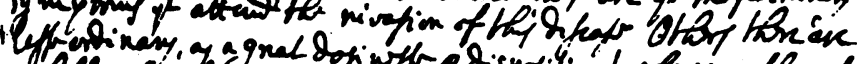

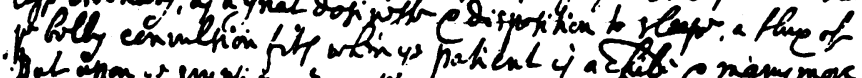

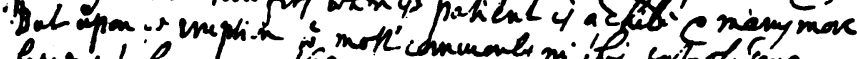

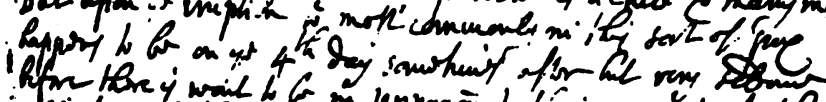

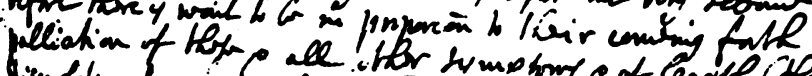

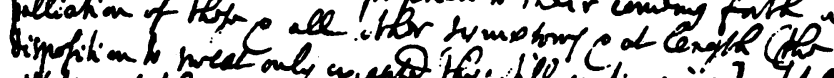

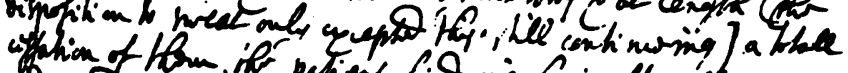

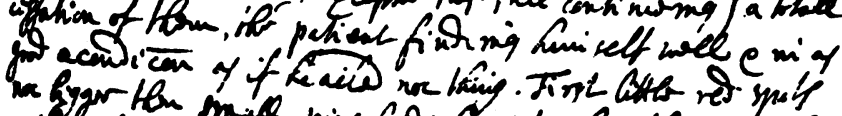

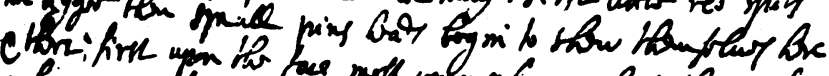

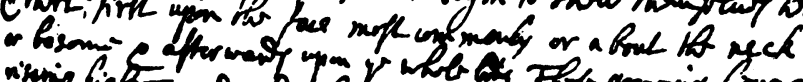

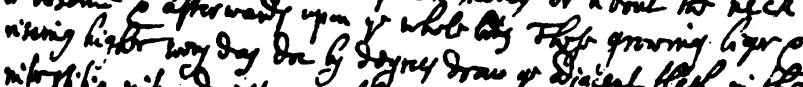

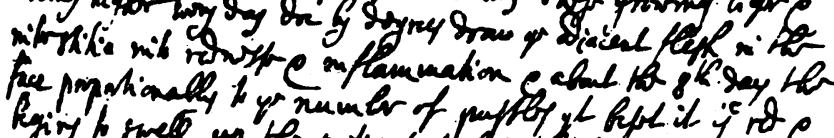

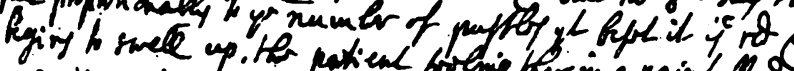
$\times$ reti-it. d.18

Fig. I

The first page of Sydenham's Essay on Smallpox copied by Locke into his notebook

(MS. Locke, f. 2I, p. 3) 


\section{Kenneth Dewhurst}

was written by both of them; De Arte Medica (1669)* is in Locke's hand; Tussis $\dagger$ (undated) is also their joint work, whereas Respirationis Ususł (undated) is the only work in Latin written entirely by Locke. It may well be that these papers were first read at meetings of a small club, formed by Locke, which met at his rooms at Exeter House to discuss medical, scientific, theological and philosophical topics. Amongst the medical members were Mapletoft, Sydenham and David Thomas. It is highly probable that Sydenham got the theoretical stimulus, and the personal encouragement from these meetings, which prompted him to put his further clinical observations in print. And it was at a meeting of this club that Locke first presented a draft of his famous Essay on Human Understanding; although the philosophers have overlooked the downright empiricism which is to be found, to a greater degree, in his medical essays (particularly De Arte Medica) than in his better known philosophical works.

Sydenham and Locke also helped one another in medical practice. The latter sought Sydenham's advice when Lord Ashley was gravely ill with a suppurating hydatid abscess of the liver;§ and Dr. E. T. Withington\| has published clinical histories from one of Locke's notebooks which includes a reference to W. Sydenham, aged eleven (son of Dr. Thomas Sydenham) who was suffering from measles. It is almost certain that Locke consulted Sydenham during his treatment of Lady Dorothy Cooper (Lord Ashley's daughter-in-law) who miscarried and was gravely ill as a consequence, before she eventually bore his lordship a grandson.

During the five years of their close association Locke and Sydenham were well-matched colleagues. The fruits of Sydenham's greater clinical experience were reaped in full measure by the less practical Locke, who also had something to offer in return. He was an experienced secretary, a classical scholar with a knowledge of the basic sciences cognate to medicine, and, as the physician to one of London's most patrician families, he was well placed to bring Sydenham's views to the notice of people of rank and fortune. But it is not generally known that both Locke and Mapletoft assisted Sydenham more directly by helping him to get his views in print, as he had the practical man's dislike of writing. There is good evidence to show that Locke did some of Sydenham's secretarial work prior to 1672, and, at a later date, Mapletoft prepared Sydenham's manuscripts for publication and translated them into Latin.

As we have seen, Sydenham and Locke were particularly interested in the treatment of smallpox, a disease which had increased in severity after the publication of Sydenham's first book in I666. And in the light of his further experience Sydenham modified his views on treatment which he decided to present as a separate work. Locke agreed to help him, and, as he had already assured himself of the efficacy of Sydenham's methods, he wrote a preface for the proposed work, together with a dedication to his patron Lord Ashley. These manuscripts

\footnotetext{
* P.R.O. File 30/24/47/2, fols, 38-47, reproduced in The Physician's Art, by A. G. Gibson (1933), O.U.P., Pp. I-13. † P.R.O. File 30/24/47/2.

\$ Osler, Sir W., An Alabama Student and other Essays, Oxford (1920), pp. $69-74$.

II Withington, E. T., 'John Locke as a Medical Practitioner', Janus (1899), rv, 393, 457, 527 and 579; also Med. Mag. (1898), vir, 47,375 and 573 .
} 


\section{Sydenham's Original Treatise on Smallpox}

in Locke's handwriting (though obviously written in Sydenham's name), are to be found amongst the Shaftesbury papers at the Public Record Office, where (although frequent references have been made to them) they have hitherto remained unpublished. Locke's copy of Sydenham's original essay has only recently come to light amongst the Lovelace papers at the Bodleian Library. Thus, for the first time, we can read Sydenham's original English instead of the various translations from Latin.

But before accepting these manuscripts as the original writings of Thomas Sydenham, it is essential to present the evidence supporting this view. Locke's copy of Sydenham's treatise on smallpox is to be found in his medical commonplace book of 239 pages, dated $1669 . *$ There is a Latin prescription in Sydenham's handwriting on the first page, and the next sixteen closely written pages are taken up by this essay on smallpox which ends with the following concise statement as to its author: 'Written by that Great Genius of Physick Dr. Sydenham in July I669'. Shortly afterwards Sydenham put down his views on 'the black pox' which Locke duly copied into his notebook with the following introduction:

Of this black pox before he had found out the cure of it the Dr writ as followeth: 'Since my writeing the foregoing discourse of the small pox I have further observed ... , which he ends with this advice: 'I am apt to believe that bleeding joyned with moderate keeping will do well'.

This second instalment is in Locke's handwriting on a separate manuscript dated ${ }_{4}$ February $1669 / 70 . \dagger$ Judging by the numerous corrections, it may well have been dictated by Sydenham and, at a later date, copied by Locke into his notebook. This important direct evidence (the accuracy of which we have no grounds for questioning) is further substantiated by much collaborative evidence. Amongst the Lovelace Papers are several essays in Sydenham's handwriting on pleurisy, dysentery, intermittent fevers, etc., which Locke carefully copied into one or other of his medical commonplace books. Hence there are good grounds for assuming that this essay on smallpox is also an exact copy of the original, as it mirrors the downright, robust style of Sydenham, rather than Locke's more sophisticated composition. Furthermore, all Sydenham's original writings which have come down to us (apart from the occasional Latin prescription) are in English. This point was conceded by Latham ${ }_{\ddagger}^{+}$in the course of a well-argued defence of the originality of Sydenham's works. 'It is a material and admitted fact', he writes, 'that the general belief of medical scholars is against the original Sydenham being in Latin.' There are good reasons for believing that Mapletoft translated Sydenham's English into Latin. The evidence is largely based on a letter§ by the Reverend John Mapletoft '(the physician's son), wherein he states that his father translated all Sydenham's works prior to 1683 , which

* MS. Locke, f. 2 I, pp. 3-19.

$\dagger$ MS. Locke, C. 29, f. 22, reproduced in the British Medical Fournal, 13 August 1955, pp, 432-3 by K. Dewhurst.

† Latham, R. G., Ed., The Works of Thomas Sydenham, (MDCCCXLVIII), I, Introd., 50.

$\S$ Gentleman's Magazine, (1 743). XIII, 528 . 


\section{Kenneth Dewhurst}

includes all his medical writings except Schedula Monitora, said to have been translated by Mr. Havers. Furthermore, a comparison of the Latin style of Sydenham's Observationes Medicae with the Gresham Lectures of Dr. Mapletoft supports this view. Latham* describes Mapletoft's Latin as being 'over idiomatic', which, he adds, is 'a characteristic of both the Latin Sydenham and of Mapletoft's Orations'.

But why was this essay on smallpox never published separately, as Locke (in Mapletoft's absence) could easily have done the Latin translation? In fact Sydenham published nothing after the second edition of his Methodus Curandi Febres came out in 1668 until his Observationes Medicae appeared eight years later. A simple and adequate explanation offers itself by tracing the movements of Locke and Mapletoft during these eight years. When Sydenham was writing this treatise on smallpox in I669/70 Mapletoft was in Copenhagen with the diplomatic mission of the Earl of Essex, and Locke, as we have seen, had come to replace him as Sydenham's closest medical colleague. It is not known how long Mapletoft remained abroad on this occasion, but Locke $†$ wrote to him on Io July 1670, adding the following postscript: 'Dr. Sydenham desires to be very kindly remembered to you'. Mapletoft was abroad again two years later. This time he accompanied the Countess of Northumberland to France where he stayed for nearly two years. During this period Locke became more heavily engaged with affairs of state (following Shaftesbury's promotion to Lord Chancellor), and he bemoans the fact that these duties allowed him little time for medical work in the following letter to Mapletoft written on I4 February $1672 / 3+$ :

Dr. Sydenham and I mention you sometimes, for we do not now meet often, my business now allowing me but little leisure for visits; but I hope I shall in a short space bring it to better terms.

He did. Shortly after Shaftesbury's fall from power Locke returned to Oxford where he took his degree of Bachelor of Medicine, and was subsequently appointed a medical don at Christ Church. But he did not stay there long, as he was worried about his health. After consulting Sydenham,§ who warned him 'that bodys broken with business' lacked the necessary 'store of needful heat', Locke decided to seek a warmer climate, and early in 1675 he left for France where he remained for the next three and a half years. He was in Montpellier when he heard that Shaftesbury was a prisoner in the Tower; and Mapletoft's same letter gave him the news that Sydenham's Observationes Medicae had appeared. Locke tried in vain to get a copy before he left Montpellier for Paris, which he mentions in this reply to Mapletoft|:

My service, I beseech you, to all my friends in your walks, particularly to Dr. Sydenham. The spell held till I had left Montpellier, for by all the art and industry I could use, I could not

* Latham, R. G., The Works of Thomas Sydenham, (MDCCCXLVIII), I, 62.

$\dagger$ Locke to Mapletoft, Io July I670; cf. European Magazine, xIv (1 788 ), 321 .

† Locke to Mapletoft, 14 February $1672 / 3$, European Magazine, xrv (1 788), 402.

§ P.R.O. File 30/24/47/2; see also 'Sydenham's Letters to John Locke', by Kenneth Dewhurst, Practitioner (1955), CLXXI, 314-20.

|| Locke to Mapletoft, 22 June 1677, European Magazine, Xv (1 789), 10.

282 


\section{Sydenham's Original Treatise on Smallpox}

get a book of his to Montpellier till the week after I had left it. I shall be glad to hear that it every day gains ground, though that be not always the fate of useful truth, especially at first setting out. I shall perhaps be able to give him an account of what some ingenious men think of it here; though I imagine he is so well satisfied with the truth in it and the design that made him publish it, that he matters not much what men think. And yet there is usually a great and allowable pleasure to see the trees take and thrive in our time which we ourselves have planted.

The preface and dedication of Sydenham's Observationes Medicae were completely different from those written by Locke and reproduced hereafter. Had Sydenham wished to use the original preface (which was most unlikely) he would have been unable to get at the manuscript which was locked up with Locke's other papers at Exeter House; whilst the distinguished patron to whom the original treatise had been dedicated was also locked up in the Tower. Times had changed. And in Locke's absence abroad the role of Sydenham's collaborator had reverted to Mapletoft: it was to him that the book was rightly dedicated. But Sydenham* also acknowledged his earlier indebtedness to Locke in the preface, wherein he pays tribute to his sound judgment on medical matters:

You know also how thoroughly an intimate and common friend, and one who has closely and exhaustively examined the question, agrees with me as to the method that $I$ am speaking of; a man who, in the acuteness of his intellect, in the steadiness of his judgment, in the simplicity (and by simplicity I mean excellence) of his manners, has, amongst the present generation, few equals and no superiors. This praise I may confidently attach to the name of fohn Locke.

Before presenting Sydenham's essay another manuscript, which is in some respects similar to the present text (insofar as it treats of smallpox), requires a word of explanation. This manuscript of 114 folios, entitled Medical Observations by Thomas Sydenham, $\uparrow$ dated 26 March 1669 , was presented to the Royal College of Physicians in 1795 by Mr. P. Le Vaillant. As we know that Sydenham incorporated most of his early views on smallpox into his later published works, we would, therefore, expect to find similarities between the College manuscript and the present essay. With certain important exceptions this is generally found to be true. But there is definite internal evidence which proves that the College manuscript was written some years after the present treatise; and, indeed, some chapters (if not all) were written after the publication of Sydenham's Observationes Medicae ( 1676$)$. One chapter headed 'Epidemical Diseases of the Year 1673' ends with the following sentence:

All this, at least that which contains the history and cure of acute diseases I have brought into my late book entitled Observationes Medicae, etc., in which book my observations are more perfect than in this manuscript. $\ddagger$

It is quite certain, therefore, that this College manuscript cannot be the original English text of what was afterwards Sydenham in Latin. After

* Latham, R. G., Ed., The Works of Thomas Sydenham, (MDCCCXLVIII), I, 6.

$\dagger$ MS. entitled Medical Observations by Thomas Sydenham, in the library of the Royal College of Physicians. $\ddagger$ MS. Sydenham, Royal College of Physicians. 


\section{Kenneth Dewhurst}

examining it I am inclined to agree with Latham, ${ }^{*}$ who states that 'it has the appearance of being a translation from the Latin rather than the original basis from which a Latin translation might have been made'. There are many examples of sentences which are so Latin in their character and phraseology as to exhibit further internal evidence of their being translations. Such a sentence (and there are many other examples) is the following:

This fever began to be grassant at the end of the spring, contrary to the indoles of the fever, preceding ...†

It was written by several hands, which (apart from the odd sentence which may be by Sydenham himself) cannot be identified. Nevertheless, we can conclude with certainty that the whole volume is a rough translation of Sydenham's Medical Observations, made by persons unknown, sometime after its publication in 1676 .

It is now necessary to offer a brief explanation of the method I have adopted in transcribing these manuscripts. Both Locke and Sydenham used many abbreviations which have been written out in full in this text. There are such obvious ones as 'yt' (that), 'ye' (the), 'wch' (which), 'sd' (said), 'agn' (again),

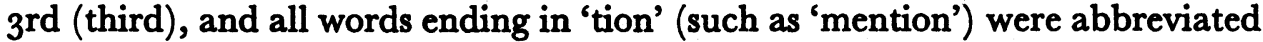
to 'ion'. Occasionally they used less well-known abbreviations such as 'phia' (philosophia), 'nāal' (natural) and 'māal' (material). Locke's handwriting, though small, is neat and fairly easy to read, as can be seen from the first page of his notebook. But he obviously wrote the preface and dedication to this essay in great haste as there are frequent alterations and additions between the lines, which, together with the variable spelling, make it difficult to decipher. This may well have been due to the fact that the whole essay was dictated by Sydenham to Locke who at a later date copied it into his medical commonplace book. Apart from writing out the abbreviations in full, the only other alteration has been the addition of a minimum of punctuation wherever its absence obscures the meaning.

\section{Epistle‡}

\section{Dedicatory to the First Edition}

I know he takes but an ill way of gratitude and makes but ill use of the favour of a great man who ventures to prefix his name to a lie and desires the patronage of a noble person to gain credit to a falsehood and make it passe the more unquestionable in the world. This consideration alone, had I noe regard to truth, conscience, and the lives of men, would make me very wary how, after the many favours I have received from your lordship and the trust you have reposed in me, I returnd you such an affront to your lordship and made you an accomplice in a cheat of no lesse a concernment than the lives of men, by publishing to the world under your protection the cure of a disease dangerous and fatall to those who shall by my profession be

* Latham, R. G., The Works of Thomas Sydenham, (MDCCCXLVIII), I, Introd., 55.

$\dagger$ MS. Sydenham, Royal College of Physicians.

$\ddagger$ P.R.O. File $30 / 42 / 2$, fols. 50-2.

284 


\section{Sydenham's Original Treatise on Smallpox}

tempted to make use of it. The world knows you are too wise a man easily to be imposed on, and I am sure you are too great a man safely to be provoked by such an imposture, and were I not by long and reitratd experience confirmd in the certainty of what I here publish, it would not become me to engage your lordships name in a controversy (for soe it is now become) which if $I$ had beene as forward that by noise and clamour to maintain, as others by reproaches, false reports, secret and open defamation have been hot to prosecute and decry, had by this time grown into a faction. It fares not always soe well with Truth and Right as not to need a patronage, new truths espetially such as stand in the way of receivd maxims and generall practice, and like trees sprouting up in the midst of the high road, which however usefull or pleasant if not fenced whilst they are young and defended till they are growne to [sic] sturdy for common injury, are sure to be trampled on in the bud and to be trod into dirt and frightfulnesse. The doctrine and method I here set forth is something of that nature. All that in their following this disease go the usuall road are apt to spurn it. It will need your lordships protection soe long till the world sees what fruit it bears and if upon triall they find it not safe and sallutary I shall willingly consent your lordship withdraw your protection from it and leave it and the author to that scorne and contempt which he shall deserve who trifles with the lives of men. Or out of a perverse and disingenious obstinate persisting in adhesion to an old error or a new mistake, for both are equally dangerous, which shall with great assurance persuade them to their distruction, and under the pretence of cureing them put them upon the most hazardous and deadly practise and by this means murder men at a distance. In the meane time it will not $I$ hope appear a very unreasonable request if $I$ desire to shelter my selfe a little while from the obliqie lies attended me for endeavouring to doe my country and age service, wherein I presume I have not been unsuccessfull, at least I must be allowed to deal soe candidly and fairly in this matter, that I put it to an easy triall and doe not by any hidden arcanamus or conceald medicins, pretend to doe wonders, and thereby gain admiration and custome a way which however suspitious in its self yet I have observd many others to practise, not only without clamour and disturbance, but even with applause and approbation, though many times those cried up preparations have produced fatal effects and most commonly very uncertain cures in the credulous takers. I say not this to undervalue the medicins of other men, but only to let your Lordship see how difficultly it has fared with me, who have under gone soe many rebukes and reproaches in the prosecution of a plain and open method, which I never indeavoured, nor indeed, could conceal from anyone who had but the curiosity to observe it, and which I thinke had noe fault unless some men will think it one to be plaine and easy and such as poor people may, to the saving their lives, make use of without the help of a physitian. But my lord I ought not to hold your lordship to long with this story. I confess $I$ have many great obligations to your lordship and am not so misled by common custom to imagine I pay any part of them by this dedication unlesse it be some kind of acknowledgment to witness to the world that I believe your lordship soe great a patriot that in the high station you are in you will not think it unworthy your care to look after the lives of your country men and to preserve them as well from your home bred diseases and foreign invasions, his majesty and your country suffering equally in both by the loss of mens lives. At least my lord I thought it reasonable to let your lordship see that $I$ have practised noething in your family but what I durst owne and publish to the world, and let my country men see that I tell them noething here but what I have already tried with noe ill successe on severall in the family of one of the greatest and most eminent personages among them. 


\section{Kenneth Dewhurst}

\section{Reader,}

\section{Preface*}

I heare present thee with a history and cure of a disease which however but too ill knowne both by its terrible aspect and fatall effects to most familys in England, yet as to the true state of the disease and the right method of ordering of it has hitherto laine in obscurity and the true cure hath been soe far from the ordinary practice that the very report of it hath made a great noise, and it has not scaped without the charge of a bold innovation. I say not this with disrespect to the physitians of former ages, nor reproach to the doctor of this. I know what is to be allowd to prepossession and education, receivd opinions I confess how false so ever, backed with generall uncontrold practice are not easily to be removed out of the mindes of men. And I quarell not with others for following their own maxims and methods, but yet must take the liberty to vindicate myself from the scandels and calumnys, which the doeing my duty and dealing with my patients as became an honest and conscientious man hath drawn upon me. Perhaps I had done more advantageously for myself and had without doubt better securd my owne Interest and fame if I had followed the old tract I could without much pains have directed cordialls my self or transcribed them out of bookes. It would be noe hard matter to have prescribd warmth and sweating and amidst the use of a great many comfortable things to have suffered my patient to have lived or died with great reputation. In which way of proceeding with little care and thoughtfullness I might securely have advanced my credit and profit, whilst the recovery of a patient dangerously ill, plied with store of spetious remedys suited to the common opinion had been sure by the friends and by standers, to have been looked on as the effect of my skill, and his death charged on the malignity of the disease not to be overcome by the most powerfull remedys. If, therefore, I had regarded ease and fame, Sennertus or Riverius, or almost any practitioner extant, would in this case have directed me quietly to it; I needed not have troubled my head with pensive thoughts and great labour of minde, to seek out a more effectuall method. When in the old way, however, my patient miscaried my esteem reputation and credit stood safe and unshaken. Whereas in this new understanding I am to contest not only with the disease, but most commonly, what is more uncurable, the prejudices of Relations and Assistants, the skill of over wise nurses and the receivd practice of physitians, and after all when my patient without danger and very little sicknesse has passed through the course of this troublesome disease and is arrived at perfect health it is by many lookd on but as a happy event of a rash undertaking, or the escape has been imputed to the favourablenesse of the disease, or the patients good and robust constitution who could not be kild by an irregular and unsuitable treatment. So hard is it by plain and visible effects to convince those who possessed by prejudices will not allow anything to be true which may thwart with the opinions they have been bred up in, and take it amiss to have their friends curd as much as to be cloakd out of the fashion. But if some of those (for the sober and considerate have been content to believe their eyes) who have seen this disease treated in my way have yet had doubtfull thoughts about it how much has my rashnesse and ignorance been exploded by those who haveing barely heard of my keeping my patients coole in the small pox yet neither knew me nor the success of my method. How have the good ladies been offended that I have slighted their cordialls and would not suffer the children of those who were committed to my care to die as their friends and relations had done heretofore. What

* P.R.O. File $30 / 47 / 2$, fols. 54-6r.

286 


\section{Sydenham's Original Treatise on Smallpox}

storys of extravagancy and folly have the talk of prejudicd people brought upon me, soe much that it has been told to persons of quality that I have taken those who have had the small pox out of their beds and put them into cold water. How much some of my own faculty have fomented and increasd these reports they themselves know and with what design I leave it to their owne consciences to tell them only they must give me leave to say it would have become them out of common charity as good men, as well as out of an obligation to improve their art and save mens lives as physitians, upon the first intimation of an unusuall method of cureing so common a disease as this is, to have enquired more particularly of the way, observd the circumstances, and informd them selves of the events, before they had cried it down as dangerous and fatall, and frightened all that came within their reach from an enquiry into or triall of this method of the abhorrency they had given them against so bold and hazardous a practice.

For if the way I here publish be upon examination found (as I doubt not but it will) safe and secure, free not only from danger but even sicknesse too; I fear the world will have reason to suspect that they have not that regard to truth nor that tendernesse for the health of men which befits those who professe to take care of it, and that they value not how many mens lives are sacrificied to their method and maxims, soe the reputation of their learning and their owne ways of practise be but secured. I should not make these reflections, how true soever, had I not been used by some of them with these greatest indignitys beyond almost the suffrance of a man to the endangering not only of my reputation and lively hood but even my life its self which may well deserve to be questiond if as some have reportd by unallowable practices I doe soe certainly indanger and destroy my patients. But I chalenge them and al men living to produce one instance where one patient of mine sick of the small pox being ordered my way has miscarried. Tis true sometimes when either the prejudice of friends would not suffer me to treat my patients in a way to which they were averse and sometimes when the frequent discourses have been had of me as a rash and venturous or a senseless and ignorant man came to my ears (nay I have been told even by physitians that this has been no less than a particular madnesse) I have been at a stand in my owne thoughts, distrusted my owne experience and out a desire to avoid singularity and perpetuall contention have returnd again to the old method of cureing this disease wherein if my patients have sometimes died under my care it ought to be charged upon hot keepeing and cordialls and the method in fashion and not be mentiond to disgrace the contrary way of cure which has never faild to be successful and which hereafter I cannot with a safe conscience foresake or disdain whenever I shall be cald to any sick of this disease, however desperate this method may appear to others or prove prejudiciall to my self, who am not to neglect the cure of my patient intrusted to me and of whose life I am to give an account, nor deviate from that way which I know to be best upon any so mean a consideration as quick fame or the opinion of others. This alone hath taught me, not the noise and talk of the world, and I have not without foresight of it, incurd the scorn and censures $I$ have fallen under in defence only of my patients lives and that truth I am sure posterity will thank me for. For it was not a forward affectation of novelty and opposition that made me run headlong upon this condemnd course, nor any desire to follow by paths of my owne findeing amidst thorns and bryars made me forsake the common road, but finding that notwithstanding the most diligent attendance and careful use of the choisest cordialls many, of not only mine, but other physitians patients miscarried in the small pox and many more very narrowly escaped, and were weak for a long time after. I thought it a very 


\section{Kenneth Dewhurst}

uncomfortable practice where notwithstanding the best method I could propose or saw used, the patient being governable and the assistants diligent, I could yet with noe assurance to myself or hopes to my patient undertake the cure which would be very doubtfull in the event. I first therefore bethought myself whether the sweats usually prescribed and prosecuted in the beginning might not be prejudiciall in a disease whereof Nature had designed in another way by pustles and little imposthumes. The first thing, therefore, that I decided on towards the cureing of this disease was the cuting off and preventing these sweats, which attempts had no ill successe but yet was not enough wholy to secure my patient. The next step therefore was to abate in great measure the plenty of cordialls that used to be given in the small pox, which I did but by slow degrees, for though the very nature of the disease being in it self very hot and feverish and very apt on every occasion to break out with great burning might to any observing person seem little to need such heating remedys yet my inclination to the old opinion and practice kept me long in the use of them and twas late before I left them quite off, which I retaind till my dayly experience as I forebore their use gave me new incouragement the more to forebeare them and that $I$ formd the [opinion] that those people always underwent this disease with least sicknesse and danger who took the least of them, and were most removed from hot keepeing either by clothes on their bodys or fire in their room. But findeing that in the heat of summer in people of high and sanguin constitutions and a flox pox, bare abstaining from heat and hot medicins was not enough to preserve my patient from very ill accidents and great danger soe long as I kept them in bed, I had at last venturd to make them rise wherein they found such present relief that some that have been languishing and ready to die in their beds, have upon their riseing immediately found alteration in their strength and pulse and thought themselves instantly recoverd by it. But to perfect the cure there was one thing more yet requird which I found not till this summer when through the heat of the weather or a particular constitution of the yeare the pox was in many apt to turn black and there would appear blew spots upon the skin where in few that were kept but moderately warme and with their ordinary remedys escaped. I found it therefore necessary in these actually to cool them not only by rising and wearing very thin clothes, but by giving them whey which for severall days together was the only physick or food they tooke. And by these slow steps has it beene that after long and pensive thoughts about the small pox I have in many yeares beene able to perfect the cure of this disease which besides the good successe that usually attends it, has this advantage over other methods, that the patient after the third or fourth day when the pox begins to come out has not any fever or other sicknesse dureing the whole course of the disease and saving the pain which is occasiond by the swelling of the faceand other parts and the soarnesse of the pustles is as well as at any other time of his life which at its best, is noe small argument that this is the genuin and naturall cure of the disease.

If it were necessary to raise theorys, and from thence draw probable arguments to prove that to be likely which is already veryfied in matter of fact and experience has justified to be truely the method I make use of in cureing this disease, is as capable of a fair defence and may be made out from as rationall grounds as the cure of any disease whatsoever. He that shall well consider the hystory of this disease in all its circumstances and symptons will finde reason to imagine that hot medicins and management may not be very agreeable to its safe cure for this is a disease properly of the spring, grows up with the heat of the yeare and is most dire and mortall in the sultriest part of summer. If therefore heat by the opening of the pores and provoking transpiration 


\section{Sydenham's Original Treatise on Smallpox}

serve well to carry off the vesicules, and, as it is cald, malignant matter, and by that means to discharge the disease we might well expect milder symptoms and safer events at a season when the temper of the aire most contributes to its genuine cure by opening passages of the skin and calling out the cause and occasion of all the disorder within whatever this be. So I appeal to experience and perhaps it will be found hereafter noe false nor inconsiderable observation that few or none of this diseases whose proper time of breaking out is in the spring when the bloud is of it self strong and vigorous and little needs to be inflamd by cordiall are to be curd by a hot regimen or heating medicins, which are apt to disturb other regular motions of nature, increase the disorder and by confounding the humors hinder the work she is about.

It is a disease of many sanguin people, and as it commonly soe it most dangerously seises those who are full of heat and spirit in the flourishing part of their age, and as it were the spring of their lives, and whose nature and constitution has already provided soe great strength and warmth of bloud where the heart is soe vigorous, and the spirits naturally soe unruly and apt to take harm and break out into disorder, one would suppose there were little need to add fuell to the fire. Vinum et iuventus duplex incendium, * who finds not the wine is very prejudiciall in most people till they are past the acme of their age and very apt to inflame the bloud and produce dangerous fevers, who would to a young man in the small pox already too hot with his owne temper and the burning of the disease think it convenient to give him sack and strong bere or season all he takes with peper and cloves, for what I pray are all the cordialls that are given to expel this disease but either the strong and spiritous parts of wine drawn to greater by distillation, or the aromaticall parts of vegetables unitd into some composition, and by these ways of preparation made only little more displeasing to the palat and more remote from the grateful nature of food and soe disguisd into physick. For I ask any man why canary its self or muskadell is not a better cordiall more pleasing to the taste and stomach wherein besides the spiritous vinus gravis, which alone are the cordiall, there is in its naturall composition a very delicate and greatfull realish not easily to be made by art, why I say, are not those better given them thus, that when by distillation they be turnd into Brandy tho by the addition of different but hot ingredients they are diversified into severall magnified cordiall waters and weare the gaudy names of aq. Epidemica, aq. Theriacalis stillot. whereof there are an infinit number amongst all which $I$ imagin there is to be found in reference to their use in the small pox, and all other diseases, noe other difference but their strength and relish. As to their taste there are very few that will not thinke the naturall wines them selves much better, but are not to be prescribd because they look not soe much like physick, and there is not sufficient appearance of art and learning in it, and if these cordiall waters are weaker, that is lesse hot and vitrious than sack or muscadine, why such pains to prepare them when smaller wines or diluted would better serve the turne. And if they are stronger certainly in this hot and feverish disease which never was, nor will be, cured by sweat or transpiration, they are certainly not much worse. Is it not ridiculous to see the grave old gentlewoman or the experienced nurse forbid the touching a drop of strong beare or wine in the small pox for feare it should augment the heat and give a dangerous increase to the feaver, and yet at the same time, give him the hotter and more inflaming spirits of those very liquors distild into brandy and prescribd by the doctor under the name of a cordiall and expect from this that the cause of the distemper should be brought out and the poor young gent be made cooler who perhaps got this distemper and inflamed his bloud into the small pox by

* Wine and youth both start a conflagration.

289 


\section{Kenneth Dewhurst}

drinking wine or the same sort of brandy. If therefore there were any indication for such strong liquors in this case, would not wine its self be better to which probably the patient haveing been accustomd in the time of his health his stomach would better receive a liquor that was familiar to it and which by its naturall crasis is better suited to refresh us than when that gratefull taste is destroyd by distillation and cannot by any mixtures or artifice of ours be recoverd again. It is plain therefore by their owne confession, and their condemning strong beare and wine, ordinary and familiar cordiall drinks, and those very liquors from which the others are drawn, that they think and finde by experience that hot and vinous liquors are dangerous and hurtfull in the small pox, and thereby seem to expect the good effect they promise them selves by the use of cordialls from some specific qualitys in the ingredients or composition, and does not primarily and immediately consist in that heat which they cause in the bloud when taken. But I would gladly know from any one what one specifick cordiall produces any effect in our bodys and operates any other way then a draught of good wine doth. Almost all the cordialls used in this disease being either parts of animals and vegetables (the purely minerall used being few and I think of not undoubtd efficacy) both which are noe otherwise cordiall then as they abound with either hot oyle or volatil salts both which when put into our bloud are apt to produce in it a great ebullition, the effects whereof are heat, and in bodys disposed to it, sweat. And this in short a greater ebullition fomentation or volatilization of the bloud, or what ever you call it, where of heat and a brisker circulation is alway the concomitant, is the proper and immediate effect of cordialls, and what soever is apt to excite that flamma vitalis or igniculus cordis is rankd with that classis. Now of those there are two sorts: first vegetable which consists in noething but great plenty of a volatil oyl separable from the concret by distillation, wherein spices abounding more than other principles usually carry the first rank among cordialls, and being by virtue of their hot oyle very apt to inflame the bloud, and as it were adde new and very combustible matter to it, are lookd upon as very comfortable things and apt to strengthen the heart and raise the spirits of which rank also are angelica zedoray balm and such herbs as abounds in volatil oyle. And that their chief efficacy lyes in exciting the effervescence of the bloud by their hot oyly parts is obvious to any who considers that their ordinary distilld waters haveing by that way of preparation very little of this oyle mixed with them have very little efficacy in strengthening the vitals or disposeing the body to sweat or a freer diaphoresis, and he who shall take large quantitys of these, as the chymists calls them phlegms, will not finde him selfe much warmed or revivd by them and may sooner expect to be put into a sweat by warm possett drinke then by larger quantitys of borage or buglos water however esteemd cordiall be if the actuall heat of them be not made use of to produce it.*

44 Sagacissimi viri, et practici faelicissi[mi] $D^{\text {ni }} D^{\text {ris }}$ Thomae Sydenham amici sui plurimum Colandi tractatus de Variolis $\overline{\mathrm{an}}$. $1669 . \dagger$

The Small pox of all other diseases is the most $\ddagger$ common, as that which sooner or later (at least in this part of the world) attaques most men. When it proves very epidemicall it comes in about that time of the yeare which comprehends the end of the spring and the beginning of summer, and usually runs out in a great vigor till the returne of the nexte yeare, leaveing likewise some scatterings of it self even through out an other yeare. There are only two sorts of the true pox: viz Distinct \& Flox of

* The preface is obviously unfinished.

$\dagger$ The treatise on smallpox, dated 1669 , of the author's very good friend and master, Dr. Thomas Sydenham, a man of great learning and a most successful practitioner.

$\ddagger$ MS. Locke, f. 21, pp. 3-1 7 (Bodleian Library). 


\section{Sydenham's Original Treatise on Smallpox}

which I shall here treat, omiting to mention any sort of the illegitimate ones, they being many and very different.

First the Distinct ones invade for the most part with a rigor and horror which are succeeded with a great heat, pain in the head and back, a reaching to vomit, a great tendernesse in the parts under the scrobiculus cordis when pressed with the hand, a great aptitude to sweat provided the patient be adult; these are the most ordinary symptoms that attend the invasion of this disease. Others there are less ordinary, as a great dosinesse and disposition to sleepe, a flux of the belly, convulsion fits when the patient is a childe and many more. But upon the eruption which most commonly in this sort of pox happens to be on the fourth day, sometimes after, but very seldome before, there is wont to be in proportion to their comeing forth a palliation of these, and all other symptoms, and at length (the disposition to sweat only excepted this still continueing) a totall cessation of them, the patient finding himself well and in as good a condition as if he ailed noe thing. First little red spots no bigger than small pins heads begin to show themselves here and there, first upon the face most commonly or about the neck or bosome, and afterwards upon the whole body. These growing biger and riseing higher every day doe by degrees draw the adjacent flesh in the interstitia into rednesse and inflammation, and about the eighth day, the face proportionably to the number of pustles that beset it, is red and begins to swell up, the patient feeling therein a painfull drubing and shooting at this time, but in the progresse of the disease the palpebrae are very often soe stretched with inflammation that he is not able to looke abroad till about this day, the pustles have continued smooth to the touch of ones finger and red, but from thence forward they begin to be roughish to the touch (which is the very first indicium of their being comeing to maturity) and likewise to be at least upon their heads of a yellowish colour like an honey comb. Those on the face grow more rugged and yellow every day thereafter till they scale off. But those on the hands and the rest of the body are lesse rugged and grow whiter. Those of the face and the rest of the body goe off by scaleing, those on the hands by breaking. Those of the face and rest of the body are usually dried up and gon by the fourteenth or fifteenth day but those on the hands remain green a good while after. In the place of those on the face a certain scurfe comes on which makes way for the piting. For upon the first shelling noe uneavennesse in the skin appears. But afterwards the scurfe successively comes and goes till the pits are made which we see. Though notwithstanding tis to be observed that [in] this sort of pox how large and full soever when it happens at any time between Christmas and midsomer leaves not any impression which disfigures the face as doth very often those of the contrary season of the yeare. Dureing the whole disease the body is either altogeather bound or the patient goes but very seldome to stoole. Thus much for the Destinct pox.

Secondly, The flox pox invade in the like manner as the other doe save that now and then they begin with a great pain about the region of the kidneys resembling a nephriticall paroxysme and more rarely with a pain in the side like a pleurisy either of which ways of invadeing shew that they will prove a very high flox. But invade how they will, their eruption most commonly happens to be the third day sometimes before but never after. And by how much sooner they appeare than that time by soe much the more they flox. They come forth sometimes like an Erysipelas and sometimes like the measles from which he must be a very experiensed physitian that can distinguish them and though a cough when attending such eruptions may render it probable that they will prove the measles, that doth not always hold. They rise not up in progresse of time to any considerable bulke espetially on the face as the distinct 


\section{Kenneth Dewhurst}

ones doe, but catching hold of one an other are first all over like one continued blister and swell the face as much or more than the other, but are afterwards like one continual white skin pasted on to the face and riseing not very high above the true superficies of the same. About the eighth or ninth or tenth day, the said white skin begins in some places to feele rough to the touch and from that time growes not of a yellow but browne colour and dayly increases in those two qualitys till it begins to fall off in broad fleaks, which in some parts of the face may not now and then happen in above twenty days. The shelling off of these likewise leaves noe uneaveanesse in the face at first but is succeeded with a scurfe that is of a very corrodeing nature, and doth not only at any time of the yeare whatsoever pit more than the other before mentioned but likewise endangers scauring. If it be a very high flox the cuticula will peele off in many places of the body as on the neck, shoulders and back and leave the subjacent parts raw. But all this while it constantly happens in this sort of pox that the patient if adult hath been troubled with a ptyalisme wherein the matter comes first thin and continues easy to be brought up till about the eleventh day, at what time it is very viscouse and hard to excreat. But if he be an infant he hath had a Diarrhoea nature having providently found out one of these two ways for the discharge of that matter which in these depressed pox could not be had equal with what is found in those other elevated ones before mentioned.

This disease in its self is very salutary and when not mishandled kills few or none, nature haveing annexed thereunto both a full and convenient discharge of the morbifick matter.

This is the naturall history of the small pox as comprehending the true and genuine phaenomina belonging to them as they are in their owne nature, but other anomalous accidents there are which attend the disease when unduely managed and that create very great danger to the patient. Of these I shall now treat.

Tis to be noted therefor that amongst all the anomalous accidents those which occur the eighth day in the destinct pox and the eleventh in the Flox, still reconing from the invasion, deserve the chiefest consideration in regard it will appeare (a thing which before hath not been sufficiently observed) that most who die of either of these two sorts of small pox die in one of the two days respectively. For first in the Destinct pox the unskilfull physitian findeing in the patient a great propension to sweat (which as hath been said is very incident to all adult persons in the small pox) and promiseing to himself great advantage in his businesse from breatheing out the malignityes (as he calls it) of the disease he carefully provides that the same be cherished, both by giveing cordialls and ordering a hot regimen suitable to the same. And this he doth soe much the rather because he findes the patient very well at first under this management, besides the compliance it beares with the weake conceptions of the bystanders as well as his owne. But at length the parts which should contribute both to the riseing of the pustles and the swelling of the face being by such sweats discharged, it comes to passe that the eighth day the face which at that time should begin to swell and inflame in the interstitia between the eruptions is contrary wise lanke and the said interstitia are white, though yet the pustles themselves are red and stand up high even to the very last. The sweat which till now hath been kept up on a suddain vanisheth of its owne accord and is not to be recald by the use of any cordialls how hot soever, the patient grows phreneticall, hath great inquietude, complains of great sicknesse, makes water in great quantitys very often, and in a little time after dies. But neverthelesse tis to be noted that where the small pox are but very few, the time of the yeare winter, the patient is ancient and hath been blouded, the 


\section{Sydenham's Original Treatise on Smallpox}

hot keepeing before mentioned doth not soe certainly inferre this danger of the faces not swelling and consequently the death of the patient, as where the pox are many, the season of the yeare spring or summer, the patient is young or hath lost noe bloud, and I doubt not but the recovery of some one or more under the former circumstances, though thus unduely managed, hath beene the death of many a man in the like manner treated under contrary circumstances espetially those of spring and youth to which two this danger is more espetially incident.

But now in the flox pox the day of the greatest danger and wherein most die is eleventh from the invasion for the matter of the ptyalisme which till now was crude thin and easy to bring up is at this time become viscouse and baked up: by which means the patient is in danger of being suffocated, hath a dozeing upon him, and labours under a great stupidity, the parts being clogd and loaden, in which agony he often times dies. Though as I have said before, this accident of a ptyalisme is naturall to adult persons in the flox pox, yet that the matter thereof should bake up to such a degree as to cause the dire symptoms here mentioned, is very unnaturall, and what would not happen if the patient were moderately kept.

Other accidents there are which occur at any time of the small pox, and are common to both sorts of them. As sometimes the patient through the too intense ebullition of his bloud from cordialls and hot keepeing becomes phreneticall, sometimes from the same causes, in this disease as in the Pest its self, the compages* of the bloud being dissolved through the violence of the inflammation purple spots appeare scatterd up and downe between the pustles and prove the certain messengers of death. This most espetially happens when the constitution of the aire is very epidemicall as to this disease. Sometimes from too hot keepeing there are decernd upon the tops of the pustles little black spots noe biger than pins heads, with dimpleings in many places, which going away through the benefit of a colder regimen, grow at length to a russet color, and after that by degrees come to that yellow which is naturall to the destinct pox. I may here adde that perhaps the flox pox its self is sometimes to be accounted but an accident of the small pox, as when the variolous matter hath been thrust out too fast in the first days of the disease by hot cordialls and immoderate warme keepeing, whereby those pox are made to flox which otherwise in their owne nature would have been destinct.

Other accidents now and then acrew from contrary causes to the before mentioned ones (viz.) from suffering the patient to incurr extreme cold, or makeing undue evacuations by bleeding purgeing etc. For hence it comes to passe that sometimes the pustles grow flat and fall on a suddain and a diarrhaea comes on that indangers the patient the variolous matter being turned inwards, and nature thereby hindered from makeing a kindely discharge of the same through the habit of the body. But these and what ever accidents else depend upon this head, occur but seldome in comparison of those caused by the other (perhaps more dangerous also though less censured) extreme.

These are the anomalous accidents belonging to the small pox when unduely handled, according to which a prognostic quite different from the before mentioned one is due to the same. It being certaine that this disease in its self of all others is the most salutary, and which if left alone would kill very few or none at all, is made through the unskilfull management of physitians led away by the notion of malignity (a word that they have read in a booke) more fatall to young men espetially than perhaps any one disease whatsoever and a just occasion of reproach upon the faculty of physick.

* Compages: structure joining together (O.E.D.) 


\section{Kenneth Dewhurst}

But now what this disease is in it[s] essence I know not nor am I able to apprehend by reason of the common and naturall defects of human understanding. But never the lesse the more strict consideration of the severall phaenomena before mentioned inclines me to believe that it is an inflammation (though of a different species from all others) in the bloud and humors, wherein dureing the first three or four days, nature is intent upon the digestion of the inflamed particles, which afterwards being emandated to the habit of the body, she farther ripens and expells by way of severall small abscesses. Upon these premises it follows, that the curative indications are to be instituted according to the two times of natures digesting and expelling the inflamed particles, in both which alike she is neither to be precipitated nor retarded, but to be lead forward and helped in her owne proper pace and motion. And in the meane while the inflammation is so far to be alaid and mitigated as is consisten with the discharge of the variolous matter conformatbly whereunto this course I take is the cure.

As soone as I perceive the disease will prove the small pox, I forbid the patient to goe abroad, to eate flesh or drinke wine etc. Instead whereof I order him to feed on watergruell panado etc. and for his drinke to use small bear lightly warmed by puting a tost in it. I injoyne him to forbeare a hot regimen, and the use of any cordialls whatsoever in order to the strikeing them out before the fourth day which is the naturall and genuin time for eruption in regard it is most certain that the longer it be ere the small pox come out the more universall the separation of the variolous matter will be and consequently the better they will hold out and come to maturity, whereas the more early forceing them with a hot regimen and medecins precipitats the matter whilst it is yet crude and brings out a rather ripe fruit that very often comes to noe thing. Besides that this course indangers the turning them into a Flox pox. Nor is it of any moment that the patient in the meane time endures great sicknesse for want of their comeing out, for as much as it is harde to give an example of any one that hath died for want of their comeing out at first, provided they have not been hinderd from the same by a hot regimen and cordialls (for I have observed espetially upon young and sanguin persons) that the imposeing a hot regimen and the giveing cordialls in order to the bringing the small pox out, hath been soe far from answering that end, that it hath contrarywise frustrated the same. For the bloud being hereby heated, and put into a motion inconsistent with the separation of the variolous matter, noe more hath appeard than what only was sufficient, to declare it to have been the small pox untill such time as reduceing the bloud to a due and moderate temper by imposeing a contrary regimen I have given them an opportunity to come forth and thereby have retrieved the patient from ruin.

But at the end of the fourth day if then noe signes of eruption shall appeare, it may not be amisse to give a little Diascord. Pul. Gascon. or some such moderate cordiall in order to the strikeing them out they being now mature and ripe for separation.

After that time I forbeare the giveing any thing in order to that end, except a little draught of milke warmed and tincted with safron to be taken morning and evening till the pustles in the face are grown crusty which most commonly in the destinct pox is about the tenth day and in the flox pox about the twelfth. At what times instead of milke and safron I order five or six spoonfulls of old Malago tincted likewise with safron to be given thence forwards morning and evening till the patient be well. In regard that the crustynesse of the pustles at this time hindering the free evaporation of the streams of proceeding from this matter now growne purulent, 


\section{Sydenham's Original Treatise on Smallpox}

there is danger of the recoiling back of the said putrid streams into the mass of bloud, and consequently of the suddain death of the patient when not fortified with this or some other cordiall, and this is the true time for cordialls and not before.

But in the meane time I allow the patient to sit up some howers (according as his strength will permitt) every day dureing the whole sicknesse, provided that neither his too great soarnesse, nor the coldnesse of the season prohibit the same. And this I doe both to preserve the bloud in a due temper in this soe hot a disease as also to avoid the comeing out of sweats by which the matter is discharged that should dilute and contemporate the pox and likewise afford necessary supply for them and the swelling.

But in case, for the causes before mentioned, tis convenient to keepe the patient in bed, I suffer him however to lie with noe more clothes upon him, nor to have any other fire, that what he was accustomed to in the time of his health, nor doe I confine him to lie always in one place, but allow him the liberty of his bed, and likewise the refreshment of keepeing his armes out, provided it was his manner soe to doe when he was well.

This veryly notwithstanding the great and unreasonable prejudice entertained by the world against the same, is the true and genuin way of keepeing those that are sick of this disease, and will be found to be soe when I am in my grave. And though it will not be denied but that many recover under the use of the quite contrary regimen yet (the more is the pitty considering how safe a disease this is in its owne nature) many likewise die, and more would, if they did not owe their lives either to the coldnesse of the season wherein they were attaqued or else to their haveing (though otherwise unnecessarily) been blouded. Upon which consideration if the obstinacy of friends and the patients owne feare be such as not to suffer the keepeing before mentioned, I have always thought it more secure to take bloud, which though hurtfull in its self, in that it disturbs and confounds the separation, as also subdues the pabulum that should supply both the pustles and swelling, yet doth it a little compensate for the following hot keepeing, and there by conciliate some degree of safety to this compelled practise.

Here by the way from what hath been now said, it will appeare how easy it is to solve that common doubt how it comes to passe that in the small pox soe few die amongst the common people, in comparison of the rich, which can not be thought referable to any other cause, than that they are deprived through the narrownesse of their fortunes and their rude way of liveing of the oportunitys of hurting them selves with a more precise and tender keepeing. Though yet since they likewise of late have attained to some smattering in the notion of Malignity, and to the knowledge of Methridate hartshorne posset drinke, and other cheape ways of destroying themselves, this disease hath beene more fatall than in lesse learned though wiser ages. There being not wanting some silly woman or other in every family that is skilfull enough to contribute her part in the destruction of mankinde, but only doth lesse mischief than physitians by how much she is acquainted with fewer cordialls than they. But to returne to my businesse.

It hath been above said that in the flux pox the patient if adult is troubled with a ptyalisme, if an infant with a Diarrhaea, nature haveing provided one of those ways for the discharge of that matter which in these depressed pox could not be had equall with what is found in those other elevated ones. For this cause as I never doe endeavour the represseing of a ptyalisme in the one, soe neither doe I the stoping of a Diarrhoea in the other, both being alike absurd, and the attempting of the latter by ignorant 
persons led away (in this as in other diseases) with first notions and shadows of things hath occasiond the death of many a thousand poore infants. Wherefore leting their loosenesse run out I hold on my course, keepeing them sometimes up and sometimes in the cradell, ordering them if weaned the very same diet before mentioned. Nor doth the diarrhoea which sometimes comes in the beginning of the small pox and attends the eruption both in growne persons and infants deserve any greater consideration, provided noe artificiall evacuation hath administered occasion thereunto. For as much as I have observed that notwithstanding such a flux may give some little chek to the more speedy comeing out of the small pox neverthelesse nature will not at length faile to turne the streame of the variolous matter to the habit of the body, noe lesse than she always doth the same matter which causeth vomiting before eruption.

As to the preserveing the face from disfigureing I finde it by sufficient experience best to use noe thing at all. In regard that all oyles, liniments etc. by their moisture doe retard the drying up of the ulcers and by this delay the sanies* contained in them causes the greater excavations. But there is little danger of any mischiefe to the face provided the patient hath beane moderately kept and the pustles have not acquired a corrosivenesse and anger from too much heat. A certaine scurfe remaining after the dry scabs are fallen of [sic] which severall times peeleing off and growing again being that which in those that have been kept hot causeth the piting.

And the like may be said concerning the eys puting aside that swelling of the palpebrae which sometimes causeth blindnesse for a little time but is naturall to the disease and needeth noe other remedy saveing a little breast milk or some such slight thing now and then to be dropd in both to ease and moisten the part.

When the patient is perfectly recovered and hath eaten flesh about the space of a weeke I am carefull then to purge him and that more liberally after a flox pox or Autumnall than after Distinct or Vernall, in regard those leave the body more foule than these.

But now although this course (if carefully and wisely fitted to particular circumstances) will prevent all those unnaturall and dangerous accidents before mentioned, and render the disease most benigne and safe, yet when through the want of care and skill the said accidents have been made before I have been called, I am enforced in some particulars which I shall here recite, to alter my hand for the removeing of them.

In the first place therefor in the distinct pox if from immoderately hot keepeing and continued sweats the patients face swells not the eighth day but is lanke and lookes white in the interstitia between the pustles, in this case besides that I make all the hast I can to coole him moderately and to put him out of those sweats. I likewise order him a narcotick or about half an ounce syr. de mecon. dissolved in Cowslip water or the like, which by causeing sleepe (where the brain is not too much heated) and thereby laying a brindle upon the ferocity of the bloud gives it and the heat an oportunity to have their recourse to the face in the way that is naturall to this disease. But if the mischief depending upon this cause be soe far advanced that the sweat is allready vanished of its owne accord, the patient is become phreneticall and makes water in small quantitys very often, then I hold it too late (in regard that death is at the dore) for any other proceeding than takeing bloud or exposeing him to downright cold. Nor am I to be blamed for engageing upon this extreme, and scandall but those who create a necessity for the same, and indeed, if we shall but reflect upon the very frequent examples every one hath seen or heard of those who about this time of the disease have been recovered from the brink of destruction either by large

* Sanies: poison.

296 


\section{Sydenham's Original Treatise on Smallpox}

haemorrhages at the nose suddainly happening or by forcibly geting loose from their nurses into the cold, what I here propose will be thought to deserve the lesse reproach. Besides that tis to be considered that in this agony the great danger of death is not conversant about the pustles strikeing in (for these, as hath been said, stand up high and red to the very last) but about the faces not swelling. Now to the bringing on of this, any thing that gives temper to the bloud, which bloudletting and cooleing can not be denied to doe, must needs conduce equally and upon the same grounds with the use of Narcoticks before mentioned. But in the meane time if this shall still seeme ridiculous, this incouragement shall any one have in laughing that every silly woman to whom appeale shall be made about the absurdity of this practise, shall justify him in his mirth and magnify this deeper still, what pitty soever his ill luck may deserve.

In the next place if in the flux pox the matter of the ptyalisme through preceding heat is soe baked up as that it is become very viscous and endangers suffocation of the patient which as hath beene said is very ordinary about the eleventh day from the invasion, in this case I am carefull above all things to order gargleing of the throat and to enjoyne with great strictness the same to be donne with a syringe very often night and day. I use either small beere with hony of roses dissolved therein or this following one: Rx. liquiscit 3 drachms cortic ulmi $\frac{1}{2}$ oz fol plantag. beton ān. $\frac{1}{2}$ minim fung sambuc $\mathrm{N}^{\circ} 4$ possut enuch $\mathrm{N}^{\circ}$ I 2 fl samb. ros. rub. ān p.i coq. s. q. aq hord. ad 12 ozs colatur dissolv. mel ros $\mathrm{I} \frac{1}{2}$ ozs syr de rub Idaeo I oz. m.f. gargar injiciend cum syreng saepins die noctug.

This frequent and assiduous use of gargleing very seldom fails of freeing the patient from the ill consequences of this accident, yet never the lesse sometimes the matter of the ptyalisme is soe impact and the dosynesse soe great, that noe gargleing whatsoever will serve the turne. This doth especially happen when the pox hath invaded like a nephriticall paroxysme or like a pleurisy, both which ways of invadeing, as hath been said, doe shew that they will prove a very high flux, and consequently that this accident will be very pressing the one alway following the degree of the other for which cause whenever the small pox invade with such pains I always take bloud before eruption to prevent the bakeing up of the ptyalisme to such a dangerous heighth as will be too hard for the patient to overcome, notwithstanding any assistance given by gargles, nor have I ever yet put the issue of preventing this mischiefe upon moderate keepeing without bleeding, but judg it not absurd to have donne it in regard I am very well satisfied how great a tendency such keepeing alone hath to the preventing the same where the small pox invaded not with such pains.

As to the cure of the phrensy which in both sorts of the small pox indifferently and in any time of them is wont to be brought on by too hot keepeing and the use of cordialls, I finde the same sufficiently conquerable by altering the regimen and giveing some such narcotick as the above named. For tis carefully to be noted that every phrensy in the small pox indicates not either the bleeding or the more liberall cooleing before mentioned, but that only which happens in the distinct pox on the eighth day, and that neither (for I desire not to be mistaken) unlesse accompanied with those signes of death approaching which above I have recited.

The next of the Accidents mentioned as proceeding from too hot keepeing are noe lesse to be cured than avoided by the contrary keepeing, that of Purple spots only excepted, which declare the great malignity of the physitians practise togeather with the certainty of the patients death.

But now what ever accidents depend upon the Recoiling back of the variolous matter through incuring extreme cold or makeing undue evacuations, they are to be 
cured by the use of cordialls and a suitable regimen at least for soe long as those accidents shall last. Amongst these are chiefly to be recond the Flating of the pustles in the distinct pox (for as to the same in the flux pox tis but what is naturall to them) and likewise a Diarrhaea which for the most part attends the other but the Diarrhaea which either attends the eruption or is a concomitant of the flux pox in infants is not here meant. The same being as hath been said to be let alone. The cordiall which I commonly use is this: $\mathrm{Rx}$. aq. paralys 2 ozs aq. theriac still $\mathrm{I} \frac{1}{2}$ drachms diascord $\frac{1}{2}$ drachm elect de ov. $\frac{1}{2}$ scruple syr de mecon 2 drachms. This or the like medicin I give (and for the most part but once) not only for the removeing the above mentioned accidents but likewise when the patient complains of any sicknesse at his heart any time after full eruption.

This I thought fit to write both in regard that what I formerly published concerning this disease in a book of mine intituled, methodus curandi febres etc. was lesse perfect for want of those oportunitys of being thoroughly informed which since that time I have plentifully had espetially in the years 1667 and 68 in both which the small pox raged more than almost ever hath been knowne, and likewise for that I am abundantly sensible of the great mischiefs that are daily donne through mistakes about this disease, but espetially about its cure, wherein a great pudder is won't to be kept and the patient frightened into the endureing the torment of being kept whole weeks sweltering in his bed and of being burnt up with cordialls and all to noe other effect oftentimes than the distruction of the patient or at best his cures appearing to have been better than it was, by his haveing been made worse than he needed, both in respect of those great and dangerous accidents to which he was unnecessarily exposed dureing his sicknesse and likewise of the disfigureing impressions remaining oftentimes on his face after recovery, that otherwise would have been certainly avoided. Truly this just indignation I have both at the folly and cruelty of the received practise in this disease provokes me to appeale to the less fallible because common reason of mankinde whether the event were not to be suspected if the stoutest porter or some such person under the happyest circumstances of health and vigor should be taken from his businesse and for experiment sake should be put to bed, where with the curtains close drawne and a large fire in the roome he should be kept in a sweat or (to use a softer name) in a gentle mador for some weeks, being in the meane while carefully assisted by a nurse or two who upon the least moveing from his forme or puting a finger out of bed should correct his error by heapeing on more clothes, and dureing all this time neither the use of small beer nor anything else that is accustomary or gratefull to his palat should be allowd him, but instead thereof should be constreind to drinke posset drinke or some such mixture and likewise to take cordials of sundry kindes and in severall formes third or fourth quaque hora. For my owne part I should noe lesse suspect his life to be in hazard under such discipline, than his case to be very uneasy. But to be more serious I doubt not but that by such means as these, greater slaughters are committed and more havock made of mankinde every yeare than hath been made in any age by the sword of the fiercest and most bloudy tyrant that the world ever produced, and which makes it yet more sad, this distruction lights not upon any soe much as the youth and flourishing part of mankinde, amongst whom likewise the richest, as being the best able to be at the charges of dyeing according to art, suffer most under this calamity. But now whether I have mended the matter both in exhibiting to the world the true, if not the only history of this disease, which before lay entangled in the obscurity of notions taken up by booke men and fitted to hypotheses where with they had prepossessed themselves in their closets. Also in delivering a cure 


\section{Sydenham's Original Treatise on Smallpox}

that will render this heretofore soe fatall a disease as safe as any other whatsoever, will be the question till tis tried but noe longer. And till then I doe not beg but may reasonably challeng a belief. I know to write the history of a disease is common, but soe to doe it as not to deserve the just contempt expressed by that great Genius of Rationall nature the Lord Bacon against some undertaker of the like kinde, is somewhat more difficult Satis scimus haberi (hic de morborum historia) historiam naturalem mole amplam, varietati gratam, diligentia saepius curiosam. Attamen siquis ex eâ fabulas, et authorum citationes, et inanes controversias physiologiam denique et ornamenta eximat (quae ad convivales sermones hominumque doctorum noctes potius quam ad instituendam philosophiam sint accomodata) ad nihil magni res recidet. Longe profecto abest ab eâ historia quam animo metimur.* Also to write the cure of a disease is not lesse ordinary but soe to doe the same as to render men as potent in actions as words will be thought a greater taske by those that shall consider that every praxis abounds with the cures of those diseases which neither the author himself nor any man since could ever cure. But let me have donne the one or the other ever soe exactly, yet neverthelesse I understand the Genius of this age, and with what it is delighted, too well to expect any other reward from men save to be reproached for my pains which would have beene bestowed more advantageously to the accomodation of my fame etc. Written by the great Genius of Physick Dr. Sydenham in July 1669 .

If it be a blacke pox wherein either the pustles begin to turne black or there be blue or red or purple spots in the skin between the pustles, or it be a high flox and hot weather let them rise all day long and take noe thing but Lac Lunae. Of this black pox before he had found out the cure of it the Dr. writ as followeth.

Since my writeing the foregoing discourse of the small pox I have farther observed, that in a flox pox ordered in my way the patient begins to spit about the fifth day, his face begins to swell about the sixth, he begins to be blind about the seventh. And likewise that when the pustles are at their heigth, those on the hands and legs are large but grow lesse and lesse proportionally as upon the limbs that are placed nearer the trunck, those on the brest back and belly being very little which also about fourteenth day are most of them gon, when at the same time those on the hands and legs stand up high full and of a white colour. About the sixteenth or eighteenth day the patients legs begin to swell, which yet will sinke again after purgeing.

I have likewise met with a sort of small pox neverł before by me seen. They came forth about the second day with one generall uniforme red swelling all over the face more than an erysipelas, without the least distinction of any apparent pimples at all. In the other parts of the body very red pustules arise and besides those here and there between them especially upon the thighs severall blisters, whereof some are as big as wall nuts filled with thin water, which breaking the skins runs out and leaves the flesh under it mortified. In the progress of the disease a white silvering skin comes on upon

* The following is a rough translation:

'We know that this [he is talking on natural history of diseases] is considered a study of observed facts, of considerable bulk, pleasing diversity, and frequently displays the author's careful investigation. But if you subtract from it the stories, the quotations from authors, the empty disputes, and also the physiology and attempts at style (which are more suitable to dinnertable conversation or the symposia ${ }^{\prime}$ of educated men than to the scientific treatment of the subject) then this book becomes of little importance. It is certainly very far from that kind of history which I look for.'

$\dagger$ Hominum doctorum noctes refers to the Noctes Atticae of Aulus Gellius, wherein is a great mass of miscellaneous information on food, drink, travel, etc., in the form of after-dinner conversations between various savants.

‡ This passage has been crossed out in Locke's notebook. 


\section{Kenneth Dewhurst}

the red swelling in large patches on severall parts of the face never the lesse remaining still red. This white skin in a little while spews up a glory crusty matter which is not as in the other sorts of small pox either yellow or russet but of a deeper red colour till it come at last to a perfect black. I have seen triall both of hot and cold keeping in this species but neither of them have succeeded, though I find by how much the colder they are kept by soe much are they securer from mortifications and I am apt to believe that bleeding joyned with moderate keepeing would doe well.

In this treatise Sydenham recommends a more extreme method of treatment of smallpox than is to be found in his first book. But he still regarded the disease as being due to a new texture of the blood, rather than the result of widespread infection: in his view smallpox was physiological renewal, rather than pathological invasion, of the blood. Hence, in his first book, Sydenham urged that treatment should be directed towards aiding a natural process by bringing about separation and expulsion of the variolous matter at the right time, and in the proper degree. He argued against submitting the patient to too high an ebullition (by heating cordials and the like), which he thought would bring about a too rapid separation of variolous matter, and he was equally against following a too slow regimen by the use of purges, bleeding and cooling medicines. His initial views were moderate and essentially Hippocratic: there was nothing revolutionary nor even excessive in this early work.

But the importance of this treatise lies in the fact that it is the first example of Sydenham's cooling regimen for the treatment of smallpox. This shift of emphasis (which had far-reaching effects) was made in the light of his further experience during the widespread epidemics of 1667 and 1668 . At that time the population of London was only 500,000; and in 1667 the mortality rate was 16,000 with a birth rate of barely 11,000 . A death rate of $3 / 100$ as against a birth rate of 2/100 was an alarming state of affairs; and it is obvious from these figures that the metropolitan population could only be maintained at a constant level by the infusion of fresh blood from the country. The plague, which had swept the metropolis with volcanic fury four years previously, had now spent itself; but a combination of bad ventilation, overcrowding, poor drainage, and a general lack of cleanliness provided a ready focus for other epidemics of what are now termed preventible diseases. And of the various fevers which formed two-thirds of Sydenham's practice, smallpox carried one of the highest mortality rates with 1,196 metropolitan victims in 1667 , and 1,468 in the following year. But Sydenham believed that another factor contributed to this high mortality: the gross incompetence of the many physicians who still treated patients with heating medicines. This was his main reason for writing this treatise; and although it was never published as a separate work these same views were incorporated into a chapter entitled ' $R$ egular smallpox during the years 1667,1668 and part of 1669', which appeared seven years later in his Observationes Medicae.

This manuscript and the printed text are remarkably alike, and the few differences between them are due, for the most part, to variations in phraseology, and the usual distortions of translation. In the manuscript, for example, 


\section{Sydenham's Original Treatise on Smallpox}

Sydenham uses the term 'flux or flox pox', whereas Latham's retranslation of Mapletoft's Latin translation of the original gives 'confluent smallpox' instead. Sydenham's style of writing is more forthright and robust than the various translations would suggest. He wrote in the vigorous style of the seventeenth century, whereas the best known translation (Latham's) was written two hundred years later in the prosy language of the Victorian era. Here is an example: Latham* (p. I30, para. 21 ) writes:

In confluent smallpox the patients run the most risk, and most generally die on the eleventh day. This is the day whereon the salivation, which has hitherto been a safeguard to the patient, generally ceases of itself.

Sydenham's original English reads:

But now in the flox pox the day of the greatest danger and wherein most die is the eleventh for the invasion of the ptyalisme which till now was crude thin and easy to bring up is at this time become viscourse and baked up.

\section{Similar differences can be noted in this prophetic passage $\dagger$}

This is the true and genuine method of treating this sort of smallpox, and however much it may be opposed by the great and unfounded prejudice of the partisans of an opposite practice, it is the method which will prevail when I am dead.

The original reads

This veryly notwithstanding the great and unreasonable prejudice entertained by the world against the same, is the true and genuin way of keepeing those that are sick of the disease, and will be found to be soe when I am in my grave.

A final comparison of the phraseology of the following passages shows a clear distinction between the translation and the original.

This is the true history of this kind of smallpox; and it embraces the real and genuine phenomena of the disease as they appear in Nature. I will now discuss the accidents and irregular symptoms that supervene upon improper treatment. $\neq$ This is the naturall history of the small pox as comprehending the true and genuine phaenomina belonging to them as they are in their owne nature, but other anomalous accidents there are which attend the disease when unduely managed and that create very great danger to the patient. Of these I shall now treat.

Occasionally the two versions differ: there is some rearrangement of the context into a more logical pattern in the printed version, and some of Sydenham's more forceful comments have been left out. These views on the management of smallpox were the result of Sydenham's own clinical observations (a rare procedure in his day), and hence he seized upon every opportunity of pouring scorn on physicians whose notions were based entirely on book knowledge. An example of this is to be found in his condemnation of the

* Latham, R. G., The Works of Thomas Sydenham (MDCCGL), 1, 130, para. 21.

† Latham, R. G., The Works of Thomas Sydenham (MDCCCL), 1, 142, para. 48.

$\ddagger$ Latham, R. G., The Works of Thomas Sydenham (MDCCCL), p. 129, para. 18. 


\section{Kenneth Dewhurst}

term 'malignity' as applied to smallpox, which he dismissed as a word that 'they had read in a booke'. This rebuke, together with a number of similar ones, was left out of the printed text. Also omitted were the last few pages of raillery against physicians who still carried out a hot regimen in the management of smallpox. This was just as well, as his arguments had become repetitive.

The preface of this essay, in particular, throws further light on Sydenham's relations with his medical colleagues. It clearly shows that Sydenham had to struggle against orthodox medical opinion before his views came to be finally accepted after his death. Indeed, he even suggests that his life was threatened on account of his clinical opinions; and it it highly likely that he felt harshly used by the leaders of the profession. He was never elected a Fellow of the College of Physicians, and the reason for this sad omission has never been adequately explained. His biographer, Dr. J. F. Payne, tends to gloss over this aspect of his life. He puts forward the view that Sydenham was getting on in years when he took his Cambridge M.D. (and thereby made himself eligible for a fellowship), and hence Payne suggests that he was probably too old to care whether he got a fellowship or not. The true explanation probably lies deeper than this. It is almost certain that Sydenham's early Puritan associations, and his unorthodox opinions had something to do with his omission.

But although the citadel of orthodox medicine failed to recognize Sydenham, his merits did not escape the notice of Locke and Mapletoft. And although they both encouraged his research and helped him to get his views in print, they frequently acknowledged Thomas Sydenham, the English Hippocrates, to be their master in the sphere of clinical medicine.

\section{ACKNOWLEDGEMENTS}

I would like to thank the Trustees of the Wellcome Foundation for a grant to cover expenses; and Mr. L. M. Payne, Librarian of the Royal College of Physicians, for his advice on a college manuscript. 